\title{
Losses and dry matter recovery of Pioneiro grass (Pennisetum purpureum) and maize silages in mixtures
}

\author{
TIAGO M. SANTOS ${ }^{1}$, LUCAS LEFFERS NETO ${ }^{1}$, BRUNA L. PORTELA ${ }^{1}$, KÁTIA F. GOBBI ${ }^{2}$ AND \\ AMÉRICO F. GARCEZ NETO ${ }^{1}$ \\ ${ }^{1}$ Universidade Federal do Paraná, Laboratório de Nutrição Animal, Palotina, PR, Brazil. www.ufpr.br \\ ${ }^{2}$ Instituto Agronômico do Paraná, Estação Experimental de Paranavaí, Paranavaí, PR, Brazil. www.iapar.br
}

Keywords: Additives, effluents, gases, maize grain.

\section{Introduction}

Forages ensiled with high moisture content produce increased quantities of effluents, losing highly digestible nutrients (McDonald 1981). The silage making process usually involves gaseous and effluent losses, which are related to the moisture content of the plants used for forage conservation. The additions of material with high dry matter content and material to improve the fermentation pattern have been strategies to reduce these effluent losses. Whole maize plants and maize grain, because of their physical and fermentative characteristics, are possible materials to reduce the losses in the process (Anaya-Ortega et al. 2009). This study aimed to evaluate the effects of the addition of whole plant maize and maize grain to Pioneiro grass at ensiling as a way to reduce dry matter $(\mathrm{DM})$ losses.

\section{Methods}

The research was carried out at the Federal University of Paraná, Palotina Campus, Palotina, PR, Brazil. Pioneiro grass (Pennisetum purpureum) and maize were chopped to $20 \mathrm{~mm}$ segments and placed into PVC experimental silos with $600 \mathrm{~kg}$ of fresh mass $/ \mathrm{m}^{3}$. The silos were provided with upper Bunsen valves for the escape of gases and bottom valves to drain effluents. A completely randomized design was used, with 4 treatments and 8 replicates. The treatments involved 4 types of silage mixtures: Pioneiro grass 100\%; Pioneiro grass $90 \%+$

Correspondence: Américo F. Garcez Neto, Universidade Federal do Paraná (UFPR), Laboratório de Nutrição Animal, Campus Palotina, Palotina CEP 85950-000, PR, Brazil.

Email: americo.garcez@ufpr.br whole plant maize 10\%; Pioneiro grass $98 \%+$ maize grain $2 \%$; and whole plant maize $100 \%$. The quantities of whole plant maize and maize grain added to the treatments were calculated on a fresh mass basis.

Losses by gases (GL) and effluents (EL), and dry matter recovery (DMR) of the silages were measured. DMR was calculated using the following equation:

$\mathrm{DMR}=[($ smso $\mathrm{x}$ dmso $) /($ sme $\mathrm{x}$ dme $)] \mathrm{x} 100$, where:

$\mathrm{DMR}=$ dry matter recovery $(\%) ;$ smso $=$ silage mass at silo opening $(\mathrm{kg}) ;$ dmso $=$ dry matter at silo opening $(\% / 100) ;$ sme $=$ silage mass at ensiling $(\mathrm{kg}) ;$ dme $=$ dry matter at ensiling $(\% / 100)$.

Statistical analysis was performed using the GLM procedure and test of multiple comparison of means (SNK) at $5 \%$ level of significance by the SAS software (version 9.0).

\section{Results and Discussion}

Table 1 presents the average percentages of DM at ensiling, ensiled DM lost as gases (GL) and effluents (EL) and dry matter recovery (DMR). Silage type had a significant effect $(\mathrm{P}<0.05)$ on GL and DMR. The whole plant maize silage $(\mathrm{M})$ and Pioneiro grass silage with maize grain (PMG) had lower GL and, although differences were not significant, no EL. The large GLs of Pioneiro grass silage $(\mathrm{P})$ and Pioneiro grass silage with whole plant maize (PWPM) are likely due to lower carbohydrate and higher moisture contents of the ensiled material. As with most tropical grasses, for Pioneiro to reach a DM content comparable with the maize plant, it would need to grow for a longer period - but the increase would be at the expense of forage/silage quality. Although the effluent losses were not significant with the different DM contents, Pioneiro grass silage had the lowest DMR, which, however, could be considerably improved by adding maize grain. 
Table 1. Mean values of dry matter (DM) content at ensiling, gaseous losses (GL), effluent losses (EL) and dry matter recovery (DMR) of Pioneiro grass and maize silages in mixtures. (P: Pioneiro grass; PWPM: Pioneiro grass with whole plant maize; PMG: Pioneiro grass with maize grain; M: whole plant maize).

\begin{tabular}{lcccc}
\hline & P & PWPM & PMG & M \\
\hline DM content (\%) & $23.1 \mathrm{~d}^{1}$ & $24.2 \mathrm{c}$ & $24.9 \mathrm{~b}$ & $32.8 \mathrm{a}$ \\
GL (\% DM) & $11.14 \mathrm{a}$ & $8.65 \mathrm{~b}$ & $0.69 \mathrm{c}$ & $1.25 \mathrm{c}$ \\
EL (kg/t silage) & $2.36 \mathrm{a}$ & $0.17 \mathrm{a}$ & $0.00 \mathrm{a}$ & $0.00 \mathrm{a}$ \\
DMR (\%) & $88.78 \mathrm{~d}$ & $91.30 \mathrm{c}$ & $99.30 \mathrm{a}$ & $97.49 \mathrm{~b}$ \\
\hline
\end{tabular}

${ }^{1}$ Values within rows followed by different letters differ by SNK test $(\mathrm{P}<0.05)$.

\section{Conclusion}

High DM losses from Pioneiro silage alone are a concern in ensiling this material. Addition of maize to
Pioneiro grass when ensiling offers an excellent strategy to reduce gaseous losses and improve dry matter recovery. Mixing Pioneiro grass with whole plant maize when ensiling seems an ineffective way to reduce losses and savings might not justify the extra effort involved.

\section{References}

Anaya-Ortega JP; Garduño-Castro G; Espinoza-Ortega A; Rojo-Rubio R; Arriaga-Jordán CM. 2009. Silage from maize (Zea mays), annual ryegrass (Lolium multiflorum) or their mixture in the dry season feeding of grazing dairy cows in small-scale dairy production systems in the highlands of Mexico. Tropical Animal Health and Production 41:607-616.

McDonald P. 1981. The biochemistry of silage. John Wiley, New York, USA.

(C) 2014

\section{(c) (i) (2)}

Tropical Grasslands-Forrajes Tropicales is an open-access journal published by Centro Internacional de Agricultura Tropical (CIAT). This work is licensed under a Creative Commons Attribution-NonCommercial-ShareAlike 3.0 Unported License. To view a copy of this license, visit http://creativecommons.org/licenses/by-nc-sa/3.0/ 
Santos TM; Leffers Neto L; Portela BL; Gobbi KF; Garcez Neto AF. 2014. Losses and dry matter recovery of Pioneiro grass (Pennisetum purpureum) and maize silages in mixtures. Tropical Grasslands - Forrajes Tropicales 2:140-141.

DOI: $\underline{10.17138 / \mathrm{TGFT}(2) 140-141}$

This paper was presented at the $22^{\text {nd }}$ International Grassland Congress, Sydney, Australia, 15-19 September 2013. Its publication in Tropical Grasslands - Forrajes Tropicales is the result of a co-publication agreement with the IGC Continuing Committee. Except for adjustments to the journal's style and format, the text is essentially the same as that published in: Michalk LD; Millar GD; Badgery WB; Broadfoot KM, eds. 2013. Revitalising Grasslands to Sustain our Communities. Proceedings of the $22^{\text {nd }}$ International Grassland Congress, Sydney, Australia, 2013. New South Wales Department of Primary Industries, Orange, NSW, Australia. p. 794-795. 